\title{
THE CONCEPT OF CORRUPTION: A THEORETICAL EXPOSITION
}

\author{
Oluwatobi, O. Adeyemi \\ (1) Department of Local Government and Development Studies, Obafemi Awolowo University, Ile- Ife, \\ Nigeria. Mobile: +2348030564570 Email Korespondensi: funktob@gmail.com
}

\begin{abstract}
Abstrak: Atikel ini membahas teori dan definisi konseptual korupsi. Ini mengeksplorasi manifestasi korupsi di negara maju dan berkembang. Secara metodologis, makalah ini mengadopsi teknik pengumpulan data penelitian kualitatif melalui analisis isi studi empiris yang dilakukan oleh para sarjana klasik dan kontemporer. Beberapa dorongan teoritis dalam analisis korupsi dalam karya ini adalah Idealis, teori Fungsionalis dan pendekatan ekonomi Politik. Setelah penilaian yang cermat dan cermat terhadap pandangan ilmiah tentang korupsi, makalah ini menemukan bahwa ancaman korupsi juga nyata di negara-negara maju tetapi lebih parah di negara-negara berkembang di dunia.
\end{abstract}

Kata kunci; Korupsi; Teori; Negara Maju; Negara Berkembang.

\begin{abstract}
This paper examines the theories and conceptual definitions of corruption. It explores the manifestation of corruption in both developed and developing countries. Methodologically, the paper adopted a qualitative research technique of data collection through the content analysis of empirical studies conducted by classical and contemporary scholars. Some of the theoretical thrusts in the analysis of corruption in this work are the Idealist, Functionalist theories and Political economy approach. After thorough and careful assessment of the scholarly views on corruption, the paper discovered that the menace of corruption also manifest in developed countries but it is more acute in developing countries of the world
\end{abstract}

Keywords: Corruption; Theory; Developed Countries; Developing Countries.

Article History :

Received February 23, 2021; Revised February 29, 2021; Accepted March 23, 2021

\section{INTRODUCTION}

The term "corruption" seems to be an ambiguous and ubiquitous concept, as it tends to possess a dual nature. This ambiguity is embedded in the societal reaction to corruption. Evidently, not all kinds of corruption are censured by the society. There are some corrupt behaviours or practices that a community is prepared to condone and usually condone and others that it does not are strongly censured (Olurode 2005). In Nigeria, there are different ways of accepting a particular behaviour as corrupt or deserving of applause. For instance, those who are popularly perceived as corrupt may turn out to be loved by their communities especially if such individuals are good at providing their communities with social goods and the prosecution of these corrupt officials by anti-graft agencies may be interpreted as witch-hunting and political intimidation by their kinsmen. Therefore, corruption is one of the fundamental problems of contemporary Nigeria. It has thrived, progress and deep-rooted in the system (Adeyemi 2012:190).

In Nigeria, corruption is one of the many unresolved problems that have critically hinders development. Nigeria is one of the Sub-Sahara African states that have been identified as being very corrupt. Since independence in 1960, no administration has been declared corruption free. The first democratic government was overthrown on the ground of corruption through violent/bloody military coup by groups of military officers in January 16, 1966, thus aborting the first democratic government.

This event remains a reoccurring decimal in the political history of Nigeria because since then, there have been incessant military interventions in the polity until 1999 when the civilian administration was sworn in. So far the military has ruled Nigeria for 32 years out of its 60 years of political sovereignty. Nigeria is ranked 148 out of 180 countries in Transparency International's 2019 Corruption Perception Index (Akinpelu, 2020).

This work therefore, examines several theories that have been put forward by various scholars to explain the causes and factors responsible for corruption especially among developing societies. Some of the theoretical 
thrusts in the analysis of corruption in this work are the Idealist, Functionalist theories and Political economy approach.

\section{RESEARCH METHOD}

This article uses a descriptive research method, with the concept of a literature review. Literature review can be interpreted as a description of the theory, findings, and other research materials obtained from reference materials to be used as a basis for research activities to formulate a clear frame of mind from the formulation of the problem to be investigated.

\section{DISCUSSION}

\section{The Concept of Corruption}

Corruption is a popular term, with very rarely acceptable definition. Therefore, no general acceptable definition of corruption has emerged. In the view of above, Olopoenia (1998:17) argues thus:

Because of its nature, it is often difficult to define corruption in a way that is independent of the ethics or the normative values of the observer. This raises a number of problems in the analysis of corruption. Most people would agree that it is undesirable to seek to define the phenomenon in a value free fashion. Yet ethical definitions of any phenomenon create problems for scientific analysis; people may not agree on the ethical standard to apply; as a consequence it would be difficult to agree on the causes and effects of the phenomenon. This has constituted a major hindrance to the development of a scientifically analytical discipline in the study of corruption.

There is no gainsaying in the fact that this has constituted itself as the core of the conceptual difficulty regarding the analysis of this politically cancerous disease (corruption) which has manifested itself in most polities of the world. This conceptual difficulty is two-fold: The first concern is the actual conception of the subject-matter per se, while the second revolves around the conception of corruption in practice, or, reality within the socio-political cultures (beliefs, attitudes and values) of the developing nations (Akindele 2000:4). While the later is rooted in the multiplicity of variables for example, kinship ties, family expectations, favouritism and nepotism, the former raises moralistic and objective questions as thus:

Under what circumstances are actions called corruption...who established the standards according to which the behaviour breaks the rule... The moralist had his own idea of what the rule should be. The actors in the situation concerned have theirs. It may be the same as the moralist or quite different. They may regard themselves as behaving honourably according to their standards, or they may be men of two worlds, partly adhering to two standards which are incomparable and ending up exasperated and indifferent. (They may recognize no particular moral implications of the acts in questions at all- this is fairly obviously quite common (Leys, 1965:221)

This, among other factors, is why the attainment of definitional uniformity as to what is corruption or corrupt behaviours have been difficult. Corruption or 'level of corruption' is widely used in public discourse and usually hold a twofold common-sense meaning. On the narrow perspectives, it stands for those illegal practices, in which citizen or organisations bribes officials in charge for awarding permissions, contracts, or to escape punishment or fines for offenses they committed. In other word to obtain privileges against law or against the rules of some bureaucracy. On the broad perspective, corruption is seen as achieving several advances through personal networking; paying gratitude money or giving gifts for usual services, what are already reimbursed from customer or state resources. (The Hugarian Gallup institute, 1999). Along this line, Klitgaard (1998) defines corruption as the misuse of office for personal or unofficial ends.

Usually, the first narrow definition of corruption is primarily considered as dangerous, illegal, immoral and furthermore, totally illegitimate in today's developed or transitional societies. However, researchers indicate that narrowly defined corruption closely correlate with the level of the broader phenomenon of 'corruptive activities' or deeds which are just morally corrupt (Johnson, 1994). However, McMullan (1969:183-184) defines corruption in the following way, "a public official is corrupt if he accepts money or money's worth for doing something that he is under a duty to do anyway, that he is under a duty not to do or exercise a legitimate discretion for improper reasons". Broadly speaking, corruption is an illegal act, which involves inducement or an undue influence of people either in public or private domain to act contrary to the laid down rules and regulations which normally guide a particular process.

Corruption manifests in a variety of ways. These include: soliciting and accepting bribe before the discharge of lawful duties; nepotism, appropriation and privatization of state properties for private ends, abuse 
of official position, miscarriage of justice, undervaluation of government assets meant for disposal, lower taxes, sexual harassment in the university, electoral bribery, inflation of government contracts, examination malpractices, etc (Onuoha, 2005). Contributing to the discourse Otite (1986) sees corruption as;

\begin{abstract}
Perversion of integrity or state of affair through bribery, favour or moral depravity. It involves the injection of additional but improper transaction aimed at changing the normal course of events and altering judgments and positions of trust. It consists in doers and receivers' use of informal, extra-legal or illegal act to facilitate matter. It is in this sense that one sees corruption as a lubricator of social system, a means by which to overcome economic obstacles and bureaucratic red-tapism. Hence the ambivalence and inconsistency in the theory and practice of corruption; although it is generally regarded as a debasement of integrity, it may also serve as a nerve in social development.
\end{abstract}

From Otite's definition, corruption is seen as performing some positive and less-disruptive roles in the society. For instance, an elaborate and inefficient bureaucracy can lead to red-tapism but where graft and bribes are introduced to act as incentives, this can be reduced. He also contends that corruption provides a chance for groups other than political parties to articulate their interests, maintain a channel, and get represented in political process (Olurode, 2005). To this end, corruption is seen as having a positive impact, especially offering bribe in order to facilitate speedy transaction. However, it is preferable to encourage flexibility in administration legally than to introduce corruption as a way out of bureaucratic red-tapism since two wrong cannot make a right.

Arguing from the positive imperative of corruption, Aboyade (1971) emphasizes the need to understand the character of corruption in any society in order to arrive at a better and more realistic planning. To him, even if corruption is regarded as a vice, it should however, be noted that a private vice can cause public benefit. For instance, an individual who uses ill gotten wealth to provide social amenities and generate employment for restive youths in the society may be acting out the positive side of corruptions. Being that as it may, corruption is corruption matter how we try to colour it.

In the above views, one would like to say that, if corruption is so useful, Nzeogwu and the succession of military leaders in Nigeria would not have bothered to organize a military coup to correct certain abnormalities in the polity, especially the mass purge of civil service in 1975 and 1984/85 respectively. As Nuhu (1998:106) rightly puts it, rather such functional or utilitarian value of corruption simply fails to see that in a socially stratified (class) society, not everyone has access to or control the instrument to ensure that a corrupt practice would serve their purpose. Thus, a functional corrupt practice is only practicable to the extent that those who want the rule bent for their benefit can exercise such an influence. He further argues that, a functional or thriving corruption merely worsens the situation of less-privileged or the down-trodden in any society.

The establishment of the Code of Conduct Bureau in Nigeria through the 1979 constitution and the establishment of the Independent Corrupt Practices and other Related Offences (ICPC) and, the Economic and Financial Crimes Commission (EFCC) by Obasanjo's civilian administration in Nigeria further downplay the functionalism of corruption in any country. If it has been functional at least, in Nigeria, there would not have been any need for setting up of these bodies. On the contrary, one could equally opine that anti-graft agencies were set-up to witch-hunt oppositions or fight those with antithetical views of government policies and programmes instead out rightly fighting corruption Nwabueze (2002:128) in his own contribution adopted a sociological approach to the definition of corruption. He conceptualized corruption in the following way:

A form of social deviance in some cases, of criminal deviances, the result of failure or lack of will to respect the norms of social interactions. It is an extra-legal or normative approach to gaining access. It is a form of mal-adaptation involving the acceptance of society's cultural goals and the rejection of the socially approved means of attaining the goals. It is an indictment on the ineffectiveness of society's socialization function; a sign of some defects in the development of citizen's personality system. It indicates the existence of weakness in agencies of social control which should punish rather than reward the perpetuator of corruption.

Corruption, according to him takes several forms. On one hand, if a public officer embezzles public funds kept in his trust that is corruption. In the same vein, if he does unauthorized spending or exceeds approved limits for dubious ends, this is corruption. If he, in deviance of the rules, allocates government land to himself, his wife, his child or friends or otherwise appropriates his position to his or other person's unfair advantage, it is corruption. If he over-values a contract so that he could earn a kick-back, this is corruption. In this connection, corruption is synonymous with the abuse of office (Nwabueze, 2002).

To relate the above to Nigeria, Ayoade (1989) elaborates further on this with his model or metaphors of "egoistic and solidarity grafts", he noted that, "some public functionaries justify graft in order to redress perceived group economic disequilibrium; this is solidarity graft". Therefore, the state and its resources, both 
institutional and material, become the instrument or tool of ethnic and religious balancing. This practice has also been described as favouritism and nepotism.

The former is a mechanism of power abuse implying a highly biased distribution of state resources. The latter is a special form of the former in which an office holder prefers his/her kinfolk and family member or people of the same religion. This is a common practice in Nigeria, a situation whereby one is exempted from the application of certain laws or regulations or given undue preference in the allocation of scarce resources (Adetoye 2004:346).

On the other hand, 'egoistic graft', according to Ayoade (1989) is a situation whereby an individual enters into a shady deal for personal enrichment. In both cases, politicians and bureaucrats use the state to reward themselves and their supporters with jobs, contracts, public monopolies, and illicit income. For instance, before election or appointment into public offices, many public officials are known to have lived moderate or average life. But as soon as they assume office they become owners of many properties in different countries which their salaries cannot afford.

Corruption has also been seen by some people as being coterminous with the gift-giving and taking. There is mistaken belief by some school of thought that the practice of gift-giving and exchange of valuables in our traditional culture may promote widespread acts of corruption in the society. This phenomenon is better explained by Southhall and Gutkind (1957: 189-194) thus:

Where gift-giving is made part of transactions in modern business, the real intention to infringe and pervert rules may be concealed by continuity with an old custom. One must quickly counter this trend of thought. Gift giving as a show of appreciation for some positive deeds, good conduct or as reward for good neighbourliness should not be confused with bribes. While most gifts in traditional society are post-transaction and therefore neither an inducement nor promise to act, bribery is usually done before the act or after the act as fulfilment of promise. Gifts as rewards are part of every society's incentive reward and social control system and should not be discouraged simply because it may be misconstrued as perversion as of dubious intent which was not part of the bargain in the traditional society. Attempt must be made to separate corrupting gifts from those that help to maintain social relations and enhance positive value.

One area of the gift system which experts have rightly blamed to be conducive to corruption is the widespread expectation among citizens that public office holders have a duty to provide for their friends, neighbours, and relations. Those who do not give especially under elective dispensation may jeopardize their chances of re-election. They are thus pressurized to dip their hands in unauthorized funds to meet this socially approved expectation (Nwabueze, 2002:130). Corroborating the above statement, Adetoye (2004:347) observes thus:

Nigerians are known to celebrate appointments into public offices. Expectations of material financial assistance from such individuals by kinsman are high. They expect him to use his office to acquire financial and material gains. They confer on him chieftaincy titles and branded him unwise if after leaving office, he has not fulfilled their expectations. So, there is this norm and culture that encourage and promote corruption in the Nigerian people themselves.

Also related to the above, is the twin concepts of prebendalism and clientelism in Nigerian political system. Joseph (1999:55-56), identifies two fundamental features of the socio-political system which affect and determine, to a great extent, the allocation of public goods in Nigeria. According to him, clientelism refers to 'patron-client ties which is a common thread underlying ethnic, regional, and religious identities. It is also the channel through which one joins the dominant class and a practice that is viewed as fundamental to the continued enjoyment of the prerequisites of that class. Prebendalism on the other hand refers to a practice whereby an office of a state, is procured by individuals either through examinations or as a reward for loyal services to a lord or ruler. This is typical of feudal Europe and China.

Clientelism is more applicable in Nigeria, In this typical scenario, state resources are distributed by ethnic/social patrons who usually occupy public offices and do authoritative allocation. Such allocation is mostly done to favour their clients who in most cases are of lower socio-economic status. These clients in turn reciprocate by offering general support and assistance, including personal services to the patron. From the foregoing, we can see that corruption has generated a great concern in academic and in practices of public administration which make various writers to define and attempt to construct a model that could best describe the phenomenon.

Contributing further to this discourse, Heidenheimer (1989) classifies corruption into three categories: The first is "Public Office Centred" type which deals with abuse of public trust. official positions and responsibilities for self-serving objectives. At times, this may not result in monetary gains only but it could be a way of showing undue favour to close friends, family and kinship relations in the discharge of public functions. 
This has been worsened by 'federal character principle' or 'quotas system' which now gives leverage to geopolitical zones regarding appointments, employment and admission into institutions of higher learning. This gained public acceptance during General Ibrahim Babangida's regime.

The second variant is the Market Centred Corruption in which public office is converted to an avenue for the maximization of income and/or property as in the case of former Nigeria president, Obasanjo who used his position as the incumbent president to organize fund raising for his private presidential library in Abeokuta where billions of naira were extorted from businessmen, government agencies and private companies (Soyinka, 2015). General Sani Abacha was alleged to have stolen \$5 billion between 1993 and 1998. The greater part of the money was kept in foreign banks (Onumah 2011:155).

Another example that falls under this category is the corruption that characterised the Nigerian Police Force. This para-military organization has literarily converted Nigerian roads to Toll Plaza/Toll gates. In most cases, reluctant drivers or victims of police extortions have been shot dead for refusal or delay in giving the police as little as N10 or N20 (ten naira or twenty naira) bribes which they have somehow fixed as their unreceipted charges (Akindele \& Adeyemi, 2011:18-19).

The third variant is the Public Interest Centred Corruption, which emphasizes the abuse of public trust to serve cliental cleavages, communal and other group interests. For instances, the decision to site economic project or government agency in an unviable town because it favours the political leaders. This is a common phenomenon among the political leaders in Nigeria. This definition avoids the problem of value judgement arising from an ethical definition. It permits the extension of the notion of corruption to its public-office, market-centred and public-interest-centred manifestations.

Ruzindana (1998) aptly captures the nature of corruption in Africa. According to him, corruption in Africa is a problem of routine deviation from established standards and norms by public officials and the parties with whom they interact. He identifies the following types of corruption on the continent: bribery, extortion, illegal use of public assets for private gain, over-invoicing and under invoicing, payment of salaries and various benefits to non-existent (ghost) workers and pensioners, payment for goods not supplied or services not rendered (air supply), under-payment of taxes and duties on exports and imports through false invoicing or other declarations, purchase of goods at inflated prices, fraud and embezzlement, misappropriation of assets, court decisions awarding monetary damages in excess of any injury suffered, removal of documents or even whole case files, and nepotism and patronage.

Rose - Ackerman (1989) pointed out that a country's level of corruption depends not only on the potential for economic rent but also on the political structure. Combining these two dimensions, she identified four stylized types of corrupts states which are Kleptocracies, Bilateral monopoly states, Mafia-dominated states and Competitive-bribery states. In a pure kleptocracy, the head of government organizes the political system to maximize the possibilities for extracting rents and reallocates these rents for personal use. In the second type of corrupt state, a bilateral monopoly, a corrupt ruler faces a single major briber. The possibilities for rent extraction are shared by the briber and the ruler. In the third variant, the mafia- dominated state, is weak and disorganized, with many officials engaged in freelance bribery. As in the bilateral monopoly state, these officials face a monopolist briber in the private sector, which could be a domestic mafia or a large corporation. Finally, a competitive-bribery state is one in which many corrupt officials deal with large numbers of ordinary citizens and firms. Here, there is a potential for upward spiral of corruption. The corruption of some official can encourage other to accept bribes until all but the unreconstructed moralists are corrupt (Anifowose 2002:111).

Nigeria fall in the last category, which is a competitive-bribery state, although under the Babangida's, Abacha's and Abubarka's regimes, the country approached something of kleptocracies. For instance, under General Babangida, corruption became the directive principle of state policy. What prevailed under him was what Andreski called the 'institutionalised robbery of the state by its very custodians'. Fela Anikulapo Kuti called it 'authority stealing' (Adebanwi 2010:116). What used to be known as corruption became the art of government itself. There was a complete prebendalisation of power, and virtually all acts by public officials involving public expenditure or public goods of any kind led to the misappropriation of state finances or property by officials (lbrahim 2001:76). The routine operations of government were subjected to prebendal rules. It was widely known, for example that officials of state governments and parastatals had to pay, as they put in "up front", a percentage of their statutory allocations to the Presidency, Ministry of Finance and Central Bank Officials, before their statutory allocations were released. They in turn took their own personal shares, "up front", from the so-called government coffers (lbrahim 2001). During the above era, the officials are considered not to be corrupt since corruption has been made official.

Johnson (1998) considers this type of corruption prevalent in the developing countries including Nigeria "entrenched corruption". In such a setting, many citizens and investors see corruption as inevitable and reform as futile. There are few alternatives to dealing with corrupt officials on their terms. Those officials preserve the situation as long as they can, and few citizens or businesses are willing or able to confront them directly. Yaqub (1998:112) has argued that the height of political corruption was reached in Africa in the late sixties to the early eighties. This was particularly the case with the emergence and consolidation of personal ruler-ship. Then the 
continent was 'blessed' with the likes of Banda, Hought-Boigny, Kaunda, Toure, Amin, Bokassa, Kenyatta, Mobutu etc., who were not only dictators-for-a-while, but dictators-(presidents)-for-life. Consequent upon this travesty of ruler-ship, the state and its resources became 'private estates' that should be used as the leader deemed fit.

Some of the most absurd among this included; General Idi- Amin Dada who promoted himself to the rank of Field Marshal in the Ugandan Army and became at the same time the Chancellor or Vice-Chancellor of the erstwhile prestigious Makerere University. He in addition, declared himself the 'Conqueror of the British Empire' (CBE). There also was Bokassa who emptied his country's (Central African Republic's) treasury to crown himself an emperor over a non-existing empire. Also was Kamuzu Banda - the ex-leader of Malawi. At the height of his ruthless power, he had no Vice-president but was the commander-in-chief of the Army and the Police, and also held six ministerial portfolios - Foreign Affairs, Defence, Justice, Agriculture, Works and Supply and Home Affairs (Nuhu Yaqub 1998).

Another example of personal ruler-ship which was also a prop for corrupt practice was provided by Mobutu Sese-Seko. At the peak of his personal rule, he was alleged to have embezzled several millions of US dollar. Mobutu was also said to have been richer than his country. Though the estimate of this haemorrhage of looted capital from Africa vary, some put the figure as more than Africa's total foreign debt of around $\$ 400$ billion (Onimode, 2001:31-32). According to Abolurin (2010) corruption has led to bad government and has swallowed about $40 \%$ of Nigeria's $\$ 20$ billion annual oil income. In the process, millions of Nigerians are made poor, unemployed and uneducated.

On the same note, many of the developed countries would equally emerge with remarkably pure records, if they are to be rated according to numbers of corrupt cases recorded in some of their polity. This, among other things has generated the argument, as Yaqub (1998:106-107) depicted thus:

The phenomenon of corruption is as old as the history of man. It is not correct to see corruption as something peculiar to a particular place. It is in order in Africa to bemoan and even condemn the level (or prevalence) of corruption, but it is not only in Africa that it exist. Other examples cited from other region of the world can confirm this point. Indeed, the dynamics of corruption keeps changing from one society to another and from one time-frame to another.

The globally celebrated American Watergate (Scandal) affairs that finally cemented the then political future of ex-American President Nixon also provides a good pertinent example in this respect as does the corrupt inclination and negotiated or intended sale of President Obama's vacated Senatorial seat in the Illinois by the state Governor in 2009 following Obama's emergence as the President of the United States of America which eventually led to the death of political career of the Governor (Akindele \& Adeyemi, 2011:26). From the foregoing therefore, the menace of corruption exists in developed countries but it is more acute in developing countries.

\section{Theories of Corruption}

Extensive review of empirical literatures reveal that theories of corruption are numerous since every society conceive corruption based on its nature, ramification, manifestation, pattern, mode and appearance. However, this paper lay emphasis on the following theories of corruption due to their currency and applicability to the phenomenon under consideration:

\section{Idealist Approach}

Idealism is a philosophy that is based on the assumption that ideas which people have, determine the way they live and the way society is organized. By implication, this school of thought sees corruption and development in terms of the nature of social and moral values prevailing in the society. According to Salisu (2000:5-6) this school, sociological and or cultural factors such as customs, family pressures on government officials and ethnicity constitute potential sources of corruption. In Nigeria, although traditional values of giftgiving and tributes to leaders often lead to what Brownsberger describes as "polite corruption", the extent of such corruption is relatively microscopic. The prevalence of this kind of corruption in Nigeria is illustrated by Chinua Achebe in his novel "Things Fall Apart". Here, a strong and determined young man, called Okonkwo, went to the 'great man' of his Igbo village to ask for favour. In seeking the loan of yam seeds to plant on his farm, Okonkwo brought a cock, a pot of palm wine, a kola nut, and an alligator pepper. Offering them to the elders, he said:

Our father, l have brought you this little kola. As our people say, a man who pays respect to the Great paves way for his own greatness. I have come to pay you my respect and also to ask for favour.

Thus Okonkwo's gift-giving constitutes polite corruption (Salisu 2000). Akindele (2000:6) observes that, the rationale for this, finds solace in the fact that traditional values for example, family and kinship ties on the one hand, economic needs, poverty and dependency syndromes facing the income-earners or bread-winners on the other hand, in developing nations are realistically in disharmony with the imperatives of modern 
government or rational bureaucracy which had long spilled over into many parts of the world from their bases where such syndromes rarely exist.

Hence, corruption in most African States is viewed as a carry-over of traditional gift-giving practices. This practice anchors on the philosophy of wealth for ruler-ship because in pre-colonial times, an incumbent ruler was expected to be wealthy enough through tributes and service from the people. This was believed to enable him sponsor the traditional festivals, dole out gifts and largesse to visiting dignitaries, give alms to the poor and the needy; equip the fighting forces, etc. Thus the "ruler must provide syndrome" seems to have cast a negative shadow on our political leader to amass wealth at public expenses (Okoh, 1995:175).

The above is a case of ambivalence of civil society on the practice of corruption. The value system places the political ruler and to provide the basic necessity of life such as developing his immediate constituency. The people therefore fall back on tribalism urging their representative(s) to look after their welfare using any means at his disposal. In other word, the members of tribe or ethnic group see their kith and kin in government as being there to protect the interests of their tribal group. Hence, a government official or political ruler is supposed to bring sundry advantages to his people, he is expected to favour them, over and above tribal groups in performance of his official duties. Even where the public officer is corrupt, his people see nothing wrong in that because he is able to meet their needs with the stolen funds, It therefore, becomes extra-ordinarily difficult to take stern measures against corrupt public officers, because any prosecution of corrupt public officer is seen by his ethnic group as a carefully planned assault on the group.

Thus, a criminally responsible and monumentally corrupt warlord is seen as a hero of his state origin because of the material benefit that accrued to the state during his tenure in office (Akpotor 2003). Thus, the prosecution of the former governor of Delta State James Ibori, by EFCC and former governor of Lagos State, Ahmed Tinubu by Code of Conduct Tribunal on alleged corrupt charges was seen as witch-hunting by their various ethnic groups. The question of whether these people committed the offence for which they were being tried is not relevant here. The kinship corporation is valued over and above every conceivable (moral) principle. It is best described as indifference or active patronage. Indeed, (pervasive) argument seems to be that the national wealth is owned by nobody. Thus a public officer should plunder as much of it as possible and bring it back to his ethnic enclave for, presumably, the enjoyment of the group (Akpotor 2003). It is along this line that, this school of thought believes that, the menace of corruption can only be combated if the people are re-oriented against the evil of corruption.

This method has been adopted by various governments in Nigeria, Gowon's administration introduced "posterity" against corruption; Obasanjo's Administration as a Military Head of State introduced Jaji Declaration; Shagari's Administration introduced ethical revolution; Buhari's Administration introduced War Against Indiscipline; Babaginda's Administration established National Orientation Agency and MAMSER; and Abacha's Administration established War Against Indiscipline and Corruption, Obasanjo's Administration in Fourth Republic established EFCC and ICPC. All these institutions were established to curtail the menace of corruption in Nigeria which has eaten deep to the fabric of Nigerian society.

Going through the above theory and their analytical submission and exposition, it could be reasonably argued that this school of thought overstretches gift as the main cause of corruption while neglecting other factors such as poor wages and salaries; weak institutional system to combat corruption, lack of accountability and transparency in the conduct of government business, bad governance and leadership among others.

Also, not all gifts are bribe, Yaqub (1998: 107-108) argues that, the process of giving gifts and other acts of reciprocity that used to characterize social relations in traditional or pre-colonial societies, which idealists often regard as corruption may not likely be so. This is because in traditional settings, such acts of reciprocity could be one in which a clientelistic relationship of master and servant relationship has been forged - with the former providing protection and the later some services (including the offering of gift) as tokens of appreciation. Although this raises that dimension of how a power relationship (i.e; the structure of social justice) could have occasioned an indulgence in corrupt practices, it is apt to stress that the act of reciprocal gift-sharing was not necessarily and always a one way traffic phenomenon. In the period under reference, the master could also be the one, on occasions, that offers gifts in appreciation of loyal services from the subordinates. Therefore, it is not all gifts that facilitate corruption.

\section{The Functionalist Approach to Corruption}

Theoretically, the contribution of Robert K. Merton and Emile Durkheim remain central to any meaningful discussion of corruption as a form of criminal behaviour, indeed a deviation from cherished values of society. Merton sees the deviant behaviour or corruption in this case, as emanating from the social structure of the society which exerts a definite pressure upon certain individuals in society to engage in non- conforming rather than conforming conduct. Merton notes that much pressure is exerted on public office-holders by members of their nuclear or extended family to assist them in one way or the other. This is as a result of the fact 
that a public office holder from Local Government Councillor to Senate President or Account Manager to Director General or Chief Accountant is considered as a goldmine and proximity to the 'national cake' that should wisely be shared among family members or by either sending some people to school, setting up businesses for some and helping in-laws here and there, among other pressures (Folarin, 2009:20). This promote tendencies towards official corruption; in the same way an individual's considered wealthy may be tempted to engage in corrupt practices in order to satisfy his kinsmen. Also status change or increase is bound to increase social responsibilities as more expectations, like pressures and demands would keep coming from people. An elected Senator is not only expected to take care of his electoral constituency, but also to take care of growing number of political associates, friends, political thugs, concubines or wives, and retinues of personal staff.

Therefore, bribery, inflation of contracts and misappropriation of public funds may be seen as a way out so as to maintain the status-quo. Along this line, while each culture establishes particular goals and interests, corresponding means may not be adequate and this may lead to deviation or what Durkheim calls anomie.

Anomie to Durkheim refers to a state of normlessness.

According to Olurode (2005:20) Durkheim distinguishes between societies based on mechanical and organic solidarity. The movement of society has always been from one based on mechanical solidarity to the one based on organic solidarity. For most people who are caught in this movement, there is the transitional phase during which the norms to be followed are unclear, the Durkheimian dilemma thus arises. The mechanical society is more stable and members' behaviour is predictable whereas the organic solidarity society is in a flux and behaviour open to several possibilities. Thus for Durkheim, according to Olurode (2005) the root of deviant behaviour is social change or rather the transition of society from mechanical solidarity to organic society. Anomie results from devastating social change which causes social disorganization. Crime (corruption) is thus peculiar to an industrial society where collective conscience has been negated. Merton also gives example in competitive sports where winning the game sets a premium upon the use of illegitimate but technically efficient means. He compares this to American culture which lays great emphasis upon success without equivalent emphasis upon institutional means.

This is in line with the Machiavellian doctrine that the end justifies the means. This accounts for the high incidence of crime, particularly corruption among highly-placed business men and public officials. The above culture is rampant in Nigeria especially since the period of oil boom in 1970s. Money and property accumulation have since become the ultimate goal and 'get rich quick syndrome' has almost become a national norm in the polity. The resultant effect of this obvious discrepancy between goals and means in our society is corruption. From the above we can see that the culture of corruption is prevalent is Nigeria. Despite this analytical submission, this school of thought has also not explained thoroughly the root causes of corruption in Nigeria, the emphasis on deviant behaviour or pressure does not hold water. A political office holder may choose not to be corrupt despite incessant pressure from his family or kinship. Such exhibition of moral strength by an individual may be due to acquisition of adequate parental upbringing, principled lifestyles or religious inclination.

\section{Political Economy/ Dialectical Materialism Approach}

As a frame of reference of analysis of political phenomena, the political economy approach is derives from the writing of Karl Marx, a German philosopher. Political economy can be viewed from two stand points. Firstly, it can be viewed as a totalizing scientific mode of analysis and second, as the context within which socio-economic activities take place, and more important, as the tool for understanding the material production in societies, and construction of social forces classes (Momoh and Hundeyin 2008:38; Aina 1986:1). Karl Mark came out with a rebirth of political economy, a political economy that scientifically studies in its totality and takes into consideration the interconnection of social relations, class conflict and the organic relationship between the sub-structural (economy) and the superstructure (polity). He attempted a scientific understanding of capitalism. He thus see political economy as the science for understanding society in its entirely (Ihonvbere 1989:19; Momoh and Hundeyin 2008:43).

The theory and method of Marxian political economy is anchored on the historical and dialectical materialism. Contrary to the belief of Hegel and other idealist that consciousness is develop at the level of spirit (mind)- that an individual's consciousness is determined by idea on his/her mind, Marx believes that it is the material existence of an individual that determines his /her consciousness (Momoh and Hundeyin 2008:44).

Hence, while dialectical materialism emphasizes the contradictory nature of society, male and female, day and night, motion and rest, birth and death, consumption and excretion, positive and negative, bourgeoisie and proletariat etc. As the basic of contradiction for change and development in society (Momoh and Hundeyin 2008). This was further explains by Cornforth (1968:53) when he depicted thus; 
Dialectical materialism considers the universe not as static, not as unchanging but as a continual process of development. It considers this development, not as a smooth, continuous and unbroken process but as a process in which faces of gradual evolutionary change is interrupted by breaks in continuity, by sudden leap from one state to another. And it seek for the explanation, the driving force, of this universe movement, not on invention of the idealist fantasy but within material process themselves in the inner contradictions, the opposite conflicting tendencies that are operation in every process of nature and society.

This has been further argued that, the dialectical nature of society is the basis of its law of motion of development. In other words, the contradictions in society with the contents as the transition from quantity to quality, the law of unity and conflict of opposites and the law of the negation, as inherent in any mode of production are the basic of societal change and development. Historical materialism explains how human society has moved through the various epochal periods to date, history of human society from communalism to slavery, feudalism, capitalism, socialism, and communism. It is therefore rooted in the materialist conception of human history (Momoh and Hundeyin, 2008). According to Samon (1982:8) political economy is:

\begin{abstract}
A theoretical framework that focus on conflict, that assumes that there is systematic connection among production, power, stratification, and ideas that asserts that outcomes are largely the result of individual behaviour, that regards history as dialectical and contradictory and that presumes that both dialectical and contradiction can be understood.
\end{abstract}

Leotyen (1992) defines it as the science that deals with law governing the production and distribution of the material means subsistence in any human society at various stages of development. It refers primary to the study of political basis of economic actions, the way in which government policies affect market operation (Frieden and Lake 1995:4). Mercantilist see it as the study of the politics and its influences on the entire economy, whereas the liberalist perceive it as privacy to relative autonomy of economy and political sphere and Marxist's conceives it as the determination of political by economics (Adeyemo, 2004:14).

The above view point was further collaborated with the position of Karl Marx (1979:20-21) in his preface to a contribution to criticism of political economy when he depicted thus:

\begin{abstract}
...in the social production of their existence, people inevitable enter into definite relation which are independent of their will, namely relations of production appropriate to given stage into the development of their internal force of production. The totality of this relation of production constitute the economic structure of society, the real foundation on which arises a legal and political super structure and to what correspond definite form of social consciousness. Marx went further that the mode of production of material life condition, the general process of social political and intellectual life. It is not the consciousness of the people that determines their existence, but is their existence that determine their consciousness.
\end{abstract}

From the conceptual perspective, political economic underscores the central importance of the mode of production, and relation of production as a major casual factor in all social phenomenon (Aluko 2004:139). In advance industrialised societies, the capitalist mode of production dominates, giving rises to two major classes: the bourgeoisie and the proletariat. In Marxist analysis, the pattern of distribution of incomes and wealth and changes in this distribution over times, demonstrates the continued concentration of wealth in a small group within the general population of society. The state is therefore an organ or instrument of oppression by ruling class. It exists as a result of the irreconcilable antagonism between the bourgeoisie and the proletariat, contrary to the claims of bourgeois political economy that the state exists as a neutral regulator and unbiased moderator of antagonism of various interest in society. As Lenin argues "politics is concentrated economics". And state politics and class control are the basis of hegemony and ideological construction of all class divided societies (Abubakar and Hundeyin, 2008:46).

According to this approach, corruption is a consequence of the peripheral capitalist development system. That rather people consciousnesses determine their well being, it is the way society organizes production, distribution and exchange of goods and service that determine their material condition. In similar vein, Ninsin (2000) argues that "corruption is a form of social behaviour that is characteristic, particularly, of societies which are based on product for private use". In his view, such society place emphasis on private accumulation. In doing this, the dominant social group finds existing opportunities for private accumulation inadequate and therefore finds other means to circumvent it. Therefore, the method preferred by this dominant class will be grossly illegal, barbaric and unorthodox because it falls outside the socially approved or legal channels for personal rewards, sometimes it is characterised by reckless pursuit of power. Ake (1989:52) further noted that: 
They accumulated power by all means, did everything to secure it and to prevent others from getting it. As ruler-ship became permanent, politics became Hobbesain; power was pursued by all means and kept by all means and the struggle for power became the overriding concern. Indeed, politics became the only game played with deadly seriousness, for winners won everything and the losers lost everything.

Thus, the proponent of the approach argues that, to believe the view of the idealists that the widespread of corruption in Nigeria is due to certain inherently evil qualities or attitude is to ignore the obvious fact that man basic instincts, such as greed, selfishness and desire for property are conditioned in various ways by different socio-economic structures. This school of thought contends that, corruption in its most destructive forms in Nigeria and elsewhere has been an elite affair. Appeals to the moral conscience of masses to help rid of society of corruption are therefore a time-wasting and hypocritical approach. Consequently, the Marxist approach believes that corruption is a structural problem which derives from and has it existence in the socioeconomic organization of society.

Toyo (1980) observes that, the advantage of this approach rest on the fact that it makes analysis to be comparative, systematic and functionalist all at once, to be objective without ignoring subjective experience, general yet concrete, structuralist yet dynamic, historical yet logical, deterministic, in so far as no science can exist without some determinism, yet flexible; to see interdependence yet see super ordination and subordinate as special categories of interdependence; to see unity, to grapple with complexity yet does that in most scientifically simple way. The property that gives it this power is dialectics.

However, in spite of efficacy of dialectical historical approach, it is faced with two obstacles, firstly, the interpretation and application of Marxism approach has given rise to various schools as to the relevance of the school to African context. Secondly Marxist approach is often faced with enormous hostility arising from ideological, political and religion allegiances (Adeyemo, 2004:17). There is no doubt that, despite these shortcomings, the approach however has contributed tremendously to the advancement of knowledge by exposing the conceal realities. It provide a framework for an integrated study of political reality by making reference to relevant economy, social, legal and political factors in understanding and analysis the wide spread of corruption in Nigerian State.

\section{CONCLUSION}

This study examines the various theories and conceptual definitions of corruption. Some of the theoretical thrusts in are the Idealist, Functionalist theories and Political economy approach. The idealist school of thought sees corruption in terms of the nature of social and moral values prevailing in the society. This school of thought sees and explains corruption in terms of existence of certain selfish and hedonistic ideas which characterize the value system of any given society. Functionalist on the other hand sees corruption as a form of criminal behaviour, indeed a deviation from cherished values of society emanating from the social structure of the society which exerts a definite pressure upon certain individuals in society to engage in non- conforming rather than conforming conducts. Hence, Political economy approach views corruption as consequence of the peripheral capitalist development system but rather people consciousnesses determine their well being, it is the way society organizes production, distribution and exchange of goods and service that determine their material condition. Corruption to this school of thought is a form of social behaviour that is characteristic of societies which are based private ownership of the means of production. Such society place emphasis on private accumulation through any means which in some cases illegal. The paper therefore concludes that, the menace of corruption manifest in developed countries but it is more acute in developing countries

\section{REFERENSI}

Abolurin, A (2010) Crime Control in Nigeria, 1999-2010. Ibadan: John Archers Limited.

Aboyade, O (1971) “The Economics of Bribery and Corruption”, A Seminar Outline Faculty of Social Science, University of Ibadan, $13^{\text {th }}$ January.

Adebanwi, W. (2010) A Paradise for Maggots: The Story of a Nigerian Anti-Graft Czar. Nigeria 
Adeyemi, O. O. (2012) "Corruption and Local Government Administration in Nigeria: A Discourse of Core Issues", European Journal of Sustainable Development, Vol. 1, No. 2, European Centre of Sustainable Development

Adeyemi, O. O. (2018) "Amalgamation and the Crisis of Governance: the Nigeria Experience", Journal of Public Administration and Governance, Vol. 8, No. 3, September, Las Vegas: Macrothink Institute.

Adeyemo, D.O. (2004) "The Political Economy of Public Enterprise Reform in Ondo State", PhD Thesis, Unpublished, Department of Political Science, University of Ibadan.

Adetoye, D. (2004) "The State, Bureaucracy and Corruption in Public Offices: The Nigerian Phenomenon" in Agagu, A. A and Ola, R. F. (eds), Development Agenda of Nigerian State. Ibadan: Fiag (Nigeria) Publisher.

Aina, T. A (1986) What is Political Economy? In Nigeria Economic Society. The Nigeria Economy: A Political Economy Approach, London: Longman.

Ake, C. (1989) in Ihonvbere, J. (ed) The Political Economy of Crisis and Underdevelopment in Africa: Selected Works of Claude Ake. Lagos: JAD Publishers Ltd.

Akindele, S. T. (2000) "Corruption - Conceptualisation Problems And Institutionalisation In Nigeria: A Revisitational Examination”, Bangladesh Journal of Public Administration, Vol 1X, No. 1 and No 11

Akindele S. T. and Adeyemi, O. O. (2011) Corruption and Nigerian State: A Critical Discourse. Germany: Lambert Academic Publishing.

Akinpelu, Y (2020) Explainer: How Transparency International Assessed Nigeria's Corruption Level. Downloaded at www.premiumtimesng.com, January 28.

Akpotor, S (2003) "Corruption: the Civil Society and Government" in Maduabuchi D (ed) Philosophy and Politics: Discourse on Value and Power, Lagos: Math House Press Ltd

Aluko, F. (2004) "The Political Economy of Area Boys Phenomenon in Nigeria". Journal of Economic and Financial Studies, Vol. 1, No 1, June.

Anifowose, R. (2002) "Corruption: A Political Perspectives", in Adejugbe, M.A (ed), Perspectives on Nigeria's Fledgling Fourth Republic. Lagos: MaltHouse Press Limited.

Ayoade, J. A (1989) "Corruption and Indiscipline". A paper presented at the Training Workshop for Social Mobilization officers Organized by the Directorate for Social Mobilization, January $17^{\text {th }}-19^{\text {th }}$, at Green Spring Hotel Ibadan.

Cornforth M (1968) Dialectical Materialism: An Introduction, Vol.1, London: Laurence and Westchart 
Folarin, S. (2009): "The Anti- Corruption War in Nigeria: A Critical Appraisal of the Role of ICPC and EFCC", Nigerian Journal of Economic and Financial Crimes, Vol. 1. No 2, January - April, Abuja.

Frieden, T. F and Lake D.A (1995) (eds) International Political Economy: Perspective on Global Power and Wealth, New York: ST Martin's Press.

Heidenheimer, A. J. (1989) "Perspectives on the Perception of Corruption", in Heidenheimer, A. J, Johnson, $M$ and LeVine, V. T: Political Corruption: A Handbook, New Brunswick.

Ibrahim, J. (2001) "Manifestations and Impact of Corruption on Nigerian Society and Sustainable Democracy", in Ibrahim L. and Odekunle (eds), Fighting Corruption and Organized Crime in Nigeria: Challenges for the New Millennium. Ibadan: Spectrum Books Limited.

Ihonvbere J (ed) (1989) The Political Economy of Crisis and underdevelopment In Africa: Selected Work of Claude Ake, Lagos: JAD Publisher. Karl Marx (1979) Preface to a Contribution to the Critique of Political Economy, Moscow: Progress Publisher.

Johnson, M. (1998) "What can be done about Entrenched Corruption?" in Borris Pleskovic and Joseph Stiglitz (eds.) Corruption: Catalysts and Constraints: Report of the Annual World Bank Conference of Development Economics 1997 (The World Bank, 1998) pp. $35-57$.

Joseph, R. (1999); Democracy and Prebendal Politics in Nigeria (Ibadan, Spectrum, Books,

Karl, M. (1979) Preface to a Contribution to the Critique of Political Economy, Moscow: Progress Publisher

Klitgaard, R. (1998) "International Cooperation against Cooperation", SPAN; September/October Issue.

Leys, C. (1965) "What is Corruption about Corruption". Journal of Modern Africans Studies, Vol 3, No 2.

Leontyeu, L. (1992) “Political Economy: A Condense Course”, Moscow: Progress Publisher

McMullan, M (1961). “A Theory of Corruption”. The Sociological Review, Vol. 9, No. 2, July

Momoh, A. and Hundeyin, T. (2008) "Perspective on Political Economy, in Anifowose, R and Enemuo, F. (eds) Element of Politics, Lagos: Sam Iroanusi Publication.

Ninsi, K. A. (2000): "The Root of Corruption: A Dissenting View", In Mukandala, R. S. (Ed) (2000) African Public Administration . Zimbabwe: AAPS Books.

Yaqub, N.O. (1998) "The Prevalence of Corruption in Africa", Nnamdi Azikiwe Journal of Political Science, Vol.1. No 1. 
Nwabueze, N. (2002). "Corruption: A Sociological Perspective", in Adejugbe M.A (ed), Perspectives on Nigeria's Fledgling Fourth Republic. Lagos: Malt House Press Limited.

Olopoenia, A. A. (1998) "A Political Economy of Corruption and Under-development"; Faculty Lecture Delivered at the Faculty of Social Sciences, University of Ibadan, $7^{\text {th }}$ October

Olurode, L. (2005) "Corruption as A Social Problem", in Olurode, L. And Anifowose R. (eds), Rich But Poor, Corruption and Good Governance in Nigeria. Lagos: Faculty of Social Science, University of Lagos.

Onimode B. (2001) "Overview of corruption and Organised crime in Africa", in Ibrahim, L and Odekunle. F (eds), Fighting Corruption and Organised Crime in Nigeria: Challenges for the New Millennium. Ibadan: Spectrum Books Limited

Onuoha, B. (2005) "The State, Corruption and the Challenges of Good Governance in Nigeria", in Olurode, L. and Anifowose, R. (eds), Rich But Poor, Corruption and Good Governance in Nigeria. Lagos: Faculty of Social Science, University of Lagos.

Onumah, C. (2011)Time to Reclaim Nigeria.Abuja: African Centre for Media \& Information.

Otite, O. (1986). "On the Sociological Study of Corruption" in Odekunle, F. (ed) Nigeria: Corruption in Development, Ibadan: Ibadan University Press.

Rose - Ackerman, S. (1989) "Corruption and Development" in Borris Pleskovic and Joseph Stiglitz (eds) Corruption: Catalysts and Constraints: Report of the Annual World Bank Conference of Development Economics 1997 (The World Bank, ) pp. 35 -57.

Ruzindan, A. (1997) "Comments on What can be done about Entrenched Corruption" in Borris Pleskovic and Joseph Stiglitz (eds) Corruption: Catalysts and Constraints: Report of the Annual World Bank Conference of Development Economics 1997 (The World Bank, 1998) pp. 35 -57.

Salisu, M. A. (2000) "Corruption in Nigeria" Department of Economics, The Management School, Lancaster University.

Samon, J. (1982) “On Class Paradigm and African Politics” Africa Today, Vol. 29, NO. 2.

Shehu, A. Y. (2006). Economic and Financial crimes in Nigeria: Policy Issues and Options. Lagos: National Open University of Nigeria.

Southhall, A. W. \& Gutkind, P. C. W. (1957), Townsmen in the Making. Kampala.

Soyinka (2015) “Obasanjo’s Library a Product Fraud, Extortion and Corruption” downloaded at https://www.pmnewsnigeria.com/2015/09/11/obasanjos-library-a-product-fraudextortion-and-corruption. on August 8, 2019. 
The Hungarian Gallup Institute (1999) Basic Methodological Aspects of Corruption Measurement: Lesson Learned from the Literature and Pilot Study. Downloaded at https://www.unodc.otg/pdf/crime/corroption_hungary_rapid_assess_pdf.

Toyo, E (1980) “The Mode of Production Nucleus, As Integrator of Economic and Political Science" Nigeria Journal of Political Science, Vol. 2, No.2 December. 